\title{
Synthesis of novel precursors of Pfitzinger reaction: A facile one-pot strategy to the synthesis of quinoline carboxylic acid derivatives of pyrazolo-carbazoles and azacarbazoles
}

\author{
RUCHI TYAGI, BHAWANI SINGH* and D KISHORE \\ Department of Chemistry, Banasthali University, Banasthali (Rajasthan)-304022, India \\ e-mail: bsyadav2000@gmail.com
}

MS received 2 December 2010; revised 22 December 2011; accepted 20 January 2012

\begin{abstract}
Interaction of 5-indazolyldiazonium chloride $\mathbf{2}$ with 2-hydroxymethylidene cyclohexanone $\mathbf{5}$ and $N$-benzyl-3-hydroxymethylidene-4-piperidone $\mathbf{6}$ under the conditions of Japp-Klingemann reaction, followed by Fischer-indolization of the resulting hydrazones, formed the 5,7,8,9-tetrahydropyrazolo[4,3-b]carbazol6(1H)-one 9 and 9-benzyl-5,7,8,9-tetrahydropyrido[2',3':4,5]pyrrolo[2,3-f]indazol-6(1H)-one 10, respectively. Pfitzinger reaction of $\mathbf{9}$ and $\mathbf{1 0}$ with isatin in alkali afforded the corresponding quinoline carboxylic acid derivatives 12 and 13, respectively.
\end{abstract}

Keywords. Japp-Klingemann reaction; tetrahydropyrazolo[4,3-b]carbazol-6(1H)-one; 9-benzyl-5,7,8,9-tetrahydropyrido[2' $\left.3^{\prime}: 4,5\right]$ pyrrolo[2,3-f]indazol-6(1H)-one; Pfitzinger reaction; quinoline 4-carboxylic acid.

\section{Introduction}

The proven record of bioactive carbazoles and azacarbazoles reveal that these materials form interesting targets in synthesis, ${ }^{1}$ since such structures have potential for development of compounds with antitumor activity that could mimic to the activity of ellipticene. The ellipticene exhibits significant antitumor activity due to its DNA intercalating properties. ${ }^{2}$ Quinoline carboxylic acid and their analogues show wide variety of medicinal properties including antitumor, ${ }^{3}$ antiviral ${ }^{4}$ and estrogenic activity. ${ }^{5}$ It has been shown that 1,2,3-triazole fused quinolines exhibit photo-cleavage activity ${ }^{6}$ due to the formation of stable complex with DNA. Recent demonstrations reveal that quinoline carboxylic acid can be used as potential anticancer agents ${ }^{7}$ have stimulated further interest on these molecules with yet another perspective. Heterocyclic scaffolds bearing indole nucleus in their molecular framework are endowed with a wide array of biological activities. ${ }^{8}$ Therefore, it was considered of interest to prepare some examples of pyrazolo condensed carbazole and azacarbazole derivatives to which quinoline nucleus was appended into their

*For correspondence molecular framework to examine if such an association enhanced the DNA binding abilities of the system and produced a favourable impact on cytotoxicity in the new materials.

\section{Experimental}

Melting points were determined on an open capillary and are uncorrected. The IR spectra were recorded on Schimadzu FTIR-8400S. ${ }^{1} \mathrm{H}$ NMR spectra were recorded in DMSO- $\mathrm{d}_{6}$ and $\mathrm{CDCl}_{3}$ on Bruker DRX-300 spectrometer using TMS as internal reference and values are expressed in $\delta$ ppm. Mass spectra were taken on a Joel SX-102 (EI/CI/FAB) mass spectrometer at $70 \mathrm{eV}$. 5-Aminoindazole required in synthesis was prepared from the reduction of commercially available 5-nitroindazole. ${ }^{9}$

\subsection{General procedure for the preparation of 9 and $\mathbf{1 0}$}

2.1a Preparation of (E)-2-(2-(1H-indazol-5-yl)hydrazono)cyclohexanone 7 or (E)-3-(2-(1H-indazol-5yl)hydrazono)-1-benzylpiperidin-4-one 8 using JappKlingemann reaction: A solution of 5-indazolyl amine $1(1.00 \mathrm{~g}, 0.050 \mathrm{~mol})$ in aqueous $\mathrm{HCl}(2 \mathrm{ml}$ conc. $\mathrm{HCl}$ in $4 \mathrm{ml}$ water) was treated with a cold saturated 
solution of sodium nitrite $(0.7 \mathrm{~g}$ in $2 \mathrm{ml}$ water) while the temperature was kept at $0-5^{\circ} \mathrm{C}$. The solution was kept aside for $10 \mathrm{~min}$. It was then added portionwise to an ice-cooled mixture containing 2-(hydroxymethylene)cyclohexanone $\mathbf{5}$ or 1-benzyl-3-(hydroxymethylene)piperidin-4-one $\mathbf{6}(1.30 \mathrm{~g}, \quad 0.050 \mathrm{~mol})$, sodium acetate trihydrate $(1.80 \mathrm{~g})$ in methanol $(10 \mathrm{ml})$ and water $(6 \mathrm{ml})$ over a period of $0.5 \mathrm{~h}$ with stirring. The contents were allowed to stand for further $0.5 \mathrm{~h}$ and the resulting solid mass was filtered, washed with water and dried.

2.1b General procedure for the cyclization of hydrazones by using Fischer-indole reaction: A solution of crude hydrazone 7 or $8(0.01 \mathrm{~mol})$ suspended in a mixture of $\mathrm{HCl}: \mathrm{AcOH}(1: 4)$ was refluxed on a pre-heated oil bath to $\left(125-130^{\circ} \mathrm{C}\right)$ for $0.5 \mathrm{~h}$. The contents were then cooled and poured into ice-cooled water with stirring and then basified with ammonia. The separated brown solid was purified by passing through a column of silica gel using $50 \%$ benzene in pet ether as eluant.

2.1c 5,7,8,9-Tetrahydropyrazolo[4,3-b]carbazol-6(1H)one 9: The compound 9 was obtained by applying the general procedure mentioned above. Yield: 65\%; m.p. 238-240 ${ }^{\circ}$; IR (KBr) cm ${ }^{-1}$ : 3290, 2920, 1720, 1510, 1020; ${ }^{1} \mathrm{H}$ NMR $\left(300 \mathrm{MHz}, \mathrm{CDCl}_{3}+\mathrm{DMSO}-\mathrm{d}_{6}\right) \delta \mathrm{ppm}$ : $12.4(1 \mathrm{H}, \mathrm{s}, \mathrm{NH}), 10.1(1 \mathrm{H}, \mathrm{s}, \mathrm{NH}), 8.20(1 \mathrm{H}, \mathrm{s}, \mathrm{CH})$, $7.85(2 \mathrm{H}, \mathrm{s}, \mathrm{ArH}), 2.43\left(2 \mathrm{H}, \mathrm{t}, J=6.4 \mathrm{~Hz}, \mathrm{CH}_{2}\right), 2.10$ $\left(2 \mathrm{H}, \mathrm{m}, \mathrm{CH}_{2}\right), 1.89\left(2 \mathrm{H}, \mathrm{t}, J=6.4 \mathrm{~Hz}, \mathrm{CH}_{2}\right) ;{ }^{13} \mathrm{C} \mathrm{NMR}$ $(\delta \mathrm{ppm})$ : $\mathrm{C}(141.2,124.8,122.2,122.0$ for indazole ring), $\mathrm{CH}$ (128.9, 121.1, 112.0 for indazole ring), $\mathrm{C}$ (133.6, 124.1 for indole ring), C (183.0 for carbonyl carbon), $\mathrm{CH}_{2}$ (37.2, 26.4, 24.3 for aliphatic carbons); MS: $m / z 225\left[\mathrm{M}^{+}\right]$; Anal. calcd./found for $\mathrm{C}_{13} \mathrm{H}_{11} \mathrm{~N}_{3} \mathrm{O}$ : $\mathrm{N}, 18.52 / 18.46$.

\section{1d 9-Benzyl-5,7,8,9-tetrahydropyrido[2',3':4,5]pyr-} rolo[2,3-f]indazol-6(1H)-one 10: The compound $\mathbf{1 0}$ was obtained by applying the general procedure mentioned above. Yield: $70 \%$; m.p. $277-279^{\circ} \mathrm{C}$; IR $(\mathrm{KBr}) \mathrm{cm}^{-1}: 3220,2910,1735,1520,1040 ;{ }^{1} \mathrm{H}$ NMR

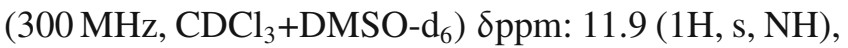
$10.8(1 \mathrm{H}, \mathrm{s}, \mathrm{NH}), 8.15(1 \mathrm{H}, \mathrm{s}, \mathrm{CH}), 7.79(2 \mathrm{H}, \mathrm{s}, \mathrm{ArH})$, 7.14-7.06 (5H, m, ArH), $4.32\left(2 \mathrm{H}, \mathrm{s}, \mathrm{CH}_{2}\right), 3.39(2 \mathrm{H}$, t, $\left.J=6.5 \mathrm{~Hz}, \mathrm{CH}_{2}\right), 2.14\left(2 \mathrm{H}, \mathrm{t}, J=6.5 \mathrm{~Hz}, \mathrm{CH}_{2}\right) ;{ }^{13} \mathrm{C}$

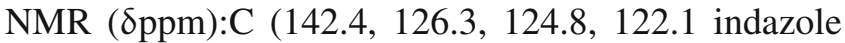
ring), $\mathrm{CH}$ (128.1, 123.1, 112.8 indazole ring), C (186.5, 135.3, 113.9 indole ring), $\mathrm{CH}_{2}$ (53.6, 37.8, 33.9 for aliphatic carbon), C (137.4 for 1-benzene), CH (129.1,
128.8, 127.9 for benzene ring); MS: $m / z 316\left[\mathrm{M}^{+}\right]$; Anal. Calcd/found for $\mathrm{C}_{19} \mathrm{H}_{16} \mathrm{~N}_{4} \mathrm{O}: \mathrm{N}, 17.71 / 17.62$.

\subsection{General procedure for the preparation of $\mathbf{1 2}$ and $\mathbf{1 3}$ from the ketone $\mathbf{9}$ and $\mathbf{1 0}$}

A solution of ketone $\mathbf{9}$ or $\mathbf{1 0}(0.07 \mathrm{~mol})$, isatin $(0.07 \mathrm{~mol})$ and potassium hydroxide $(0.2 \mathrm{~mol})$ in ethanol $(25 \mathrm{ml})$ was refluxed for $24 \mathrm{~h}$. After the distillation of most of the solvent, water was added. The neutral impurities were removed by ether extraction, and the aqueous layer was acidified with acetic acid till neutralization. The brown coloured precipitate of $\mathbf{1 2}$ or $\mathbf{1 3}$ formed was collected and recrystalized from ethanol.

2.2a 6,7,9,13-Tetrahydropyrazolo $\left[3^{\prime}, 4^{\prime}: 5,6\right]$ indolo [3, 2-c]acridine-5-carboxylic acid 12: This was prepared following the general procedure described above. Yield: $73 \%$; m. p. $208-10^{\circ} \mathrm{C}$; IR $(\mathrm{KBr}) \mathrm{cm}^{-1}$ : 3500,3300 , 2900, 1810, 1790, 1480, 1030; ${ }^{1} \mathrm{H}$ NMR $(300 \mathrm{MHz}$, $\left.\mathrm{CDCl}_{3}+\mathrm{DMSO}_{-} \mathrm{d}_{6}\right) \delta \mathrm{ppm}: 12.9(1 \mathrm{H}, \mathrm{s}, \mathrm{NH}), 11.3$ $(1 \mathrm{H}, \mathrm{s}, \mathrm{COOH}), 10.1(1 \mathrm{H}, \mathrm{s}, \mathrm{NH}), 8.25-8.87(4 \mathrm{H}, \mathrm{m}$, ArH), $8.20(1 \mathrm{H}, \mathrm{s}, \mathrm{CH}), 7.60(2 \mathrm{H}, \mathrm{s}, \operatorname{ArH}), 2.82(2 \mathrm{H}, \mathrm{t}$, $\left.J=6.4 \mathrm{~Hz}, \mathrm{CH}_{2}\right), 2.76\left(2 \mathrm{H}, \mathrm{t}, J=6.4 \mathrm{~Hz}, \mathrm{CH}_{2}\right) ;{ }^{13} \mathrm{C}$ NMR $(\delta \mathrm{ppm}): \mathrm{C}(143.4,126.1,123.7,121.3$ for indazole), $\mathrm{CH}$ (128.8, 121.5, 113.1 for indazole), C (132.2, 116.1 for indole), $\mathrm{CH}_{2}$ (24.8, 23.3 for aliphatic carbon), $\mathrm{C}(156.1,152.1,146.8,133.4,123.7$ for quinoline), $\mathrm{CH}$ (129.2, 128.7, 128.3, 123.8 for quinoline), C (168.9 for 1-carboxyl); MS: $m / z 354\left[\mathrm{M}^{+}\right]$; Anal. Calcd./found for $\mathrm{C}_{21} \mathrm{H}_{14} \mathrm{~N}_{4} \mathrm{O}_{2}$ : N, 15.81/15.73.

\section{2b 7-Benzyl-6,7,9,13-tetrahydrobenzo[b]pyrazolo[3',} $4^{\prime}$ : 5,6]indolo[3,2-h][1,6] naphthyridine-5-carboxylic acid 13: This was prepared following the general procedure described above. Yield: $75 \%$; m. p. $215-217^{\circ} \mathrm{C}$; IR (KBr) cm $\mathrm{cm}^{-1}$ : 3480, 3290, 2910, 1800, 1780, 1470, $10201030 ;{ }^{1} \mathrm{H}$ NMR $\left(300 \mathrm{MHz}, \mathrm{CDCl}_{3}+\mathrm{DMSO}_{6}\right.$ ) $\delta$ ppm: $12.1(1 \mathrm{H}, \mathrm{s}, \mathrm{NH}), 11.6(1 \mathrm{H}, \mathrm{s}, \mathrm{COOH}), 10.3$ $(1 \mathrm{H}, \mathrm{s}, \mathrm{NH}), 8.25-8.87(4 \mathrm{H}, \mathrm{m}, \mathrm{ArH}), 8.17(1 \mathrm{H}, \mathrm{s}$, CH), 7.55 (2H, s, ArH), 7.14-7.06 (5H, m, ArH), 4.37 $\left(2 \mathrm{H}, \mathrm{s}, \mathrm{CH}_{2}\right), 2.48\left(2 \mathrm{H}, \mathrm{s}, \mathrm{CH}_{2}\right) ;{ }^{13} \mathrm{C}$ NMR $(\delta \mathrm{ppm}): \mathrm{C}$ (141.8, 124.6, 123.7, 121.2 for indazole), $\mathrm{CH}$ (128.3, $121.3,112.1$ for indazole), C (158.1, 149.7, 144.7, $131.8,125.1,123.5,104.3$ for quinoline), $\mathrm{CH}$ (128.3, 127.2, 126.6, 123.4 for quinoline), $\mathrm{CH}_{2}(56.2,53.8$ for aliphatic carbon), C (137.4 for 1-benzene), CH (128.8, 128.5, 128.3, 128.1127 .8 for benzene), C (169.9 for 1-carboxyl); MS: $m / z 469\left[\mathrm{M}^{+}\right]$; Anal. Calcd/found for $\mathrm{C}_{29} \mathrm{H}_{19} \mathrm{~N}_{5} \mathrm{O}_{2}: \mathrm{N}, 14.92 / 14.84$. 


\section{Results and discussion}

The synthetic plan conceived for the preparation of the materials $\mathbf{1 2}$ and $\mathbf{1 3}$ in scheme 1 required it to be accomplished in two stages. The first stage of this strategy involved the conversion of 5-indazolyldiazonium chloride 2 to the pyrazolo fused 5,7,8,9-tetrahydropyrazolo[4,3-b]carbazol-6(1H)-one 9 and 9-benzyl-5,7,8,9tetrahydropyrido $\left[2^{\prime}, 3^{\prime}: 4,5\right]$ pyrrolo[2,3-f]indazol-6(1H)one 10 derivatives, respectively. These were realized by the interaction of $\mathbf{2}$ with 2-(hydroxymethylene)cyclohexanone 5 and 1-benzyl-3-(hydroxymethylene)piperidin-4-one 6, respectively under the conditions of Japp-Klingemann reaction, followed by the Fischer indolization of the resulting crude hydrazones with Kent's acid ( $\mathrm{HCl}: \mathrm{AcOH} ; 1: 4 \mathrm{v} / \mathrm{v})$. The compounds 5 and $\mathbf{6}$ required in the synthesis were in turn obtained, following the reported procedure ${ }^{10}$ which consisted of treating cyclohexanone $\mathbf{3}$ and $\mathrm{N}$-benzyl-4-piperidone 4, respectively with ethyl formate in the presence of sodium ethoxide. The second stage of the strategy required the conversion of $\mathbf{9}$ and $\mathbf{1 0}$ to the corresponding quinoline carboxylic acid derivatives $\mathbf{1 2}$ and 13, respectively. The Pfitzinger reaction of isatin on compounds containing the $\mathrm{COCH}_{2}$ group is known to provide a convenient one-pot synthetic entry to quinoline-4-carboxylic acid derivatives. ${ }^{11}$ It is reported $^{12}$ that enolizable ketones show great facility to condense with isatin in strongly alkaline medium to subsequently cyclize to give quinoline products. Application of this strategy on $\mathbf{9}$ and $\mathbf{1 0}$ allowed $\mathbf{1 2}$ and $\mathbf{1 3}$ to be formed in moderate to good yield.

The structure of compounds 9, 10, 12 and 13 were established on the basis of their microanalysis (for nitrogen), IR, ${ }^{1} \mathrm{H}$ NMR and MS spectral data. The data shown in experimental section were found in good agreement to the assigned structures. The IR spectra of all the compounds showed the presence of a strong absorption band near $1700 \mathrm{~cm}^{-1}$ for $\mathrm{CO}$ group. The presence of carboxylic acid group in $\mathbf{1 2}$ and $\mathbf{1 3}$ was ascertained by the appearance of a broad band of $\mathrm{OH}$ group in the region of $3500-3400 \mathrm{~cm}^{-1}$. The ${ }^{1} \mathrm{H}$ NMR spectrum displayed the corresponding peak for $\mathrm{OH}$ proton of carboxylic acid in the region of $\delta 11.0$ $\sim 11.4 \mathrm{ppm}$. The most diagnostic evidence which established the formation of the compounds $9, \mathbf{1 0}, 12$ and 13 was the appearance of the proton of indole $\mathrm{NH}$ in the region of $\delta 10.1-10.8$ in all the compounds. (The NH proton of indazole nucleus appeared at much downfield region at $\delta 12.4 \mathrm{ppm})$. The appearance of the $\mathrm{M}^{+}$peaks corresponding to their molecular formula in MS spectrum substantiated further the formation of the compounds and unequivocally established their structures.

The mechanistic pathway that rationalized the formation of $\mathbf{1 2}$ and $\mathbf{1 3}$ from $\mathbf{9}$ and $\mathbf{1 0}$ has been shown

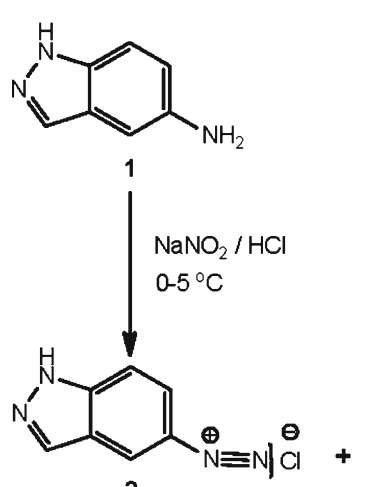

2

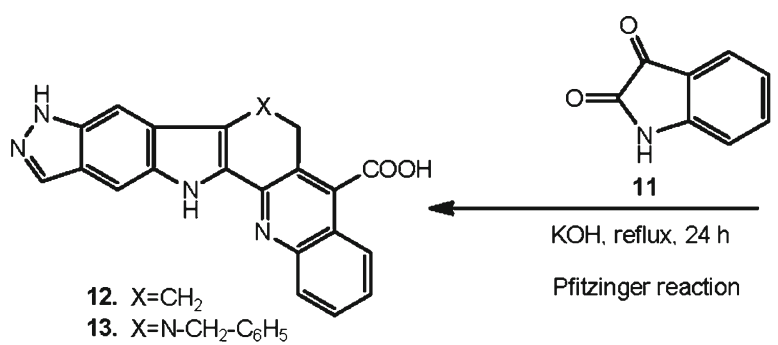

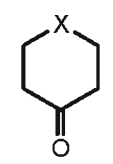

3. $\mathrm{X}=\mathrm{CH}_{2}$

4. $\mathrm{X}=\mathrm{N}-\mathrm{CH}_{2}-\mathrm{C}_{6} \mathrm{H}_{5}$

4. $\mathrm{X}=\mathrm{N}^{-} \mathrm{CH}_{2}-\mathrm{C}_{6} \mathrm{H}_{5}$ EtO-C-H/NaOEt

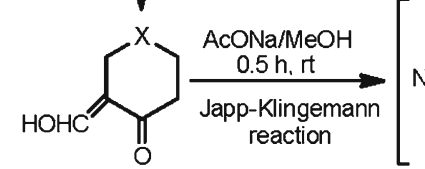

5. $\mathrm{X}=\mathrm{CH}_{2}$

6. $\mathrm{X}=\mathrm{N}-\mathrm{CH}_{2}-\mathrm{C}_{6} \mathrm{H}_{5}$

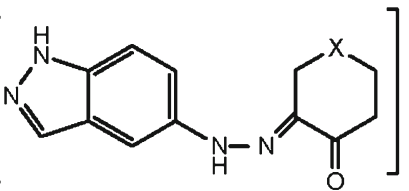

7. $\mathrm{X}=\mathrm{CH}_{2}$

8. $\mathrm{X}=\mathrm{N}-\mathrm{CH}_{2}-\mathrm{C}_{6} \mathrm{H}_{5}$

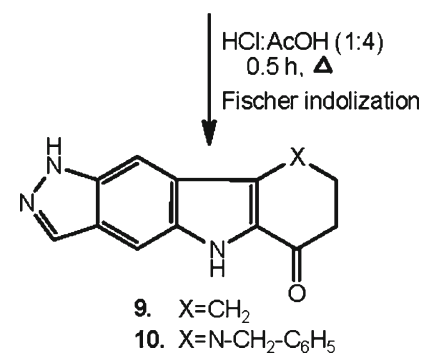

Scheme 1. Formation of $\mathbf{1 2}$ and $\mathbf{1 3}$ from $\mathbf{9}$ and 10, respectively. 


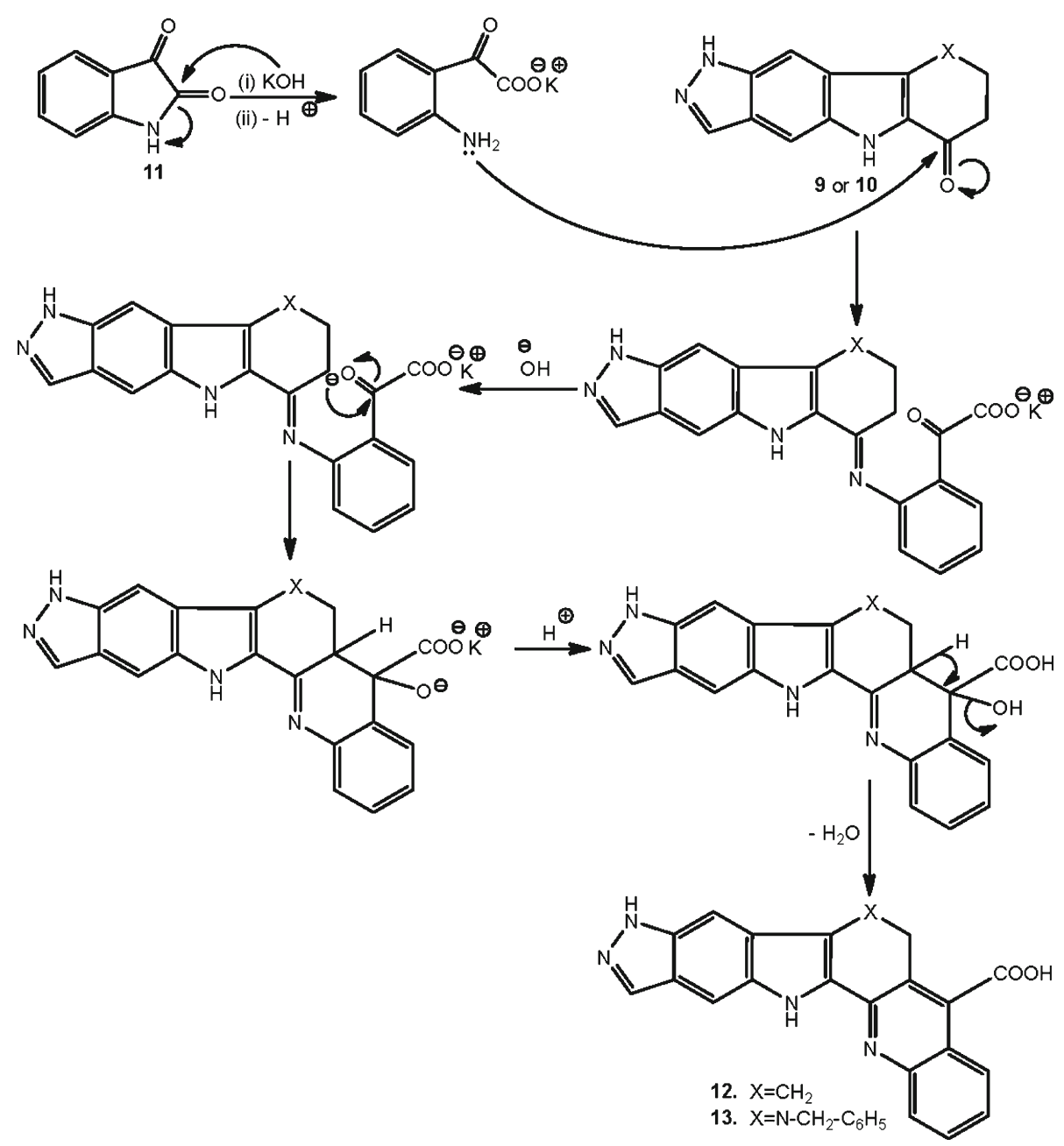

Scheme 2. Mechanism of formation of $\mathbf{1 2}$ and $\mathbf{1 3}$ from $\mathbf{9}$ and 10, respectively.

in scheme 2. It is assumed that the reaction proceeded through the formation of a non-isolable isatoic acid from isatin 11 that underwent instantaneous cyclocondensation with 9 and $\mathbf{1 0}$ to generate $\mathbf{1 2}$ and 13, respectively.

\section{Conclusion}

In conclusion, an efficient methodology for the synthesis of pyrazolo condensed oxocarbazoles and oxoazacarbazoles and their one-pot conversion to corresponding carbazolo and azacarbazolo fused quinoline carboxylic acids was developed. Heterocyclic scaffolds bearing these structures have been widely studied because of their impressive pharmacological activities. It was, therefore, reasoned that the presence of pyrazole, carbazole or azacarbazole and quinoline carboxylic acid in tandem with the same molecular framework could produce the novel heterocyclic scaffolds with interesting biological activities. Two noteworthy features of the strategy employed in synthesis of the reported compounds are apparent form our study. Firstly, it has established that the Fischer indolization of the 5-indazolyl hydrazones of cyclohexanone and $N$-benzyl substituted piperidin-4-ones provided a very convenient synthetic entry to the difficultly accessible pyrazolo fused carbazole and azacarbazole derivatives. Secondly, it has established further that the versatility of the JappKlingemann reaction to provide a one-pot synthetic approach to the preparation of heteroaryl hydrazones (on an adjacent methylene carbon of a cyclic carbonyl species) which are not normally accessible by the conventional procedures.

\section{Acknowledgements}

Authors are thankful to the Director of Central Drug Research Institute (CDRI), Lucknow and Sophisticated Analytical Instrumentation Facility (SAIF), Punjab University, Chandigarh for providing the spectral data of the compounds. 


\section{References}

1. Caruso A, Voisin-Chiret S A, Lancelot J-C, Sinicropi M S, Garofalo A and Rault S 2008 Molecules 13(6) 1312

2. Knolker H-J and Reddy K R 2002 Chem. Rev. 102(11) 4303

3. (a) Atwell G J, Baguley B C and Denny W A $1989 \mathrm{~J}$. Med. Chem. 32(2) 396; (b) Feng X U, Ding Q, Yang K and Jing W G 2006 Chinese Chem. Lett. 17(2) 187; (c) Srivastava S K, Jha A, Agarwal S K, Mukherjee R and Burman A C 2007 Anti-Cancer Agents Med. Chem. 7(6) 685

4. (a) Gramik V G, Zhidkova A M, Kiselev S S, Glushkov R G, Polezhaeva A J and Mashkovshi M D 1978 Pharm. Chem. J. 12(7) 881; (b) Dayam R, Al-Mawsawi L Q, Zawahir Z, Witvrouw M, Debyser Z and Neamati N 2008 J. Med. Chem. 51(5) 1136

5. (a) Nazrullaev S S, Bessonova I A and Akhmedkhodzhaeva K S 2001 Chem. Nat. Comp. 37(6)
551; (b) Shi F, Zhang S, Wu S-S, Gao Y and Tu S-J 2011 Mol. Divers. 15(2) 497

6. (a) Aravinda T, Bhojya Naik H S and Prakash Naik H R 2009 Int. J. Peptide Res. Therapeutics 15(4) 273; (b) Prabahkara M C and Naik H S B 2008 Biometals 21(6) 675

7. (a) Tandon V K, Yadav D B, Chaturvedi A K and Shukla P K 2005 Bioorg. Med. Chem. Lett. 15(13) 3288; (b) Musiol R, Jampilek J, Kralova K, Richardson D R, Kalinowski D, Podeszwa B, Finster J, Niedbala H, Palka A and Polanski J 2007 Bioorg. Med. Chem. 15(3) 1280

8. Eyunni V K, Kumar S, Etukala J R and Ablordeppey S Y 2008 Mini Rev. Med. Chem. 8(6) 538

9. Abdellah M, Douniazed E L A, Herard B and JeanPierre G 2006 Heterocycles 682595

10. Danish I A and Prasad K J R 2004 Indian J. Chem. 43B(7) 1548

11. Shvekhgeimer M G A 2004 Chem. Heterocyclic Comp. 40(3) 257

12. Pajouhesh H, Parson R and Popp F D 1983 J. Pharm. Sci. 72(3) 318 